\title{
The South African clothing industry: problems experienced with body measurements
}

\author{
Mariette Strydom and Helena M de Klerk
}

\section{Opsomming}

Die doel van die navorsing is om die probleme wat die Suid Afrikaanse klere-industrie ondervind, met betrekking tot liggaamsmates wat nodig is vir die vervaardiging van goedpassende klere, te ondersoek en te beskryf. Die voorsiening van klere wat aan ' $n$ drie-dimensionele liggaam pas, bly ' $n$ uitdaging, ook vir die Suid-Afrikaanse klere-industrie. Die probleme wat die verbruiker met pas ondervind kan egter nie sonder akkurate liggaamsmates aangespreek word nie.

' $n$ Kwantitatiewe navorsingsbenadering is gevolg. Posvraelyste is uitgestuur na Suid- Afrikaanse kleinhandelaars en klere-vervaardigers. Die totale teikenpopulasie is ingesluit vir die pos-opname. Die pos-opname is gevolg deur individuele onderhoude waartydens 'n gestruktureerde onderhoudskedule gebruik is. Doelbewuste steekproefneming is gebruik om 13 respondente volgens voorafgestelde kriteria te kies. Beskrywende statistiek in die vorm van frekwensietabelle is met inhoudsanalise gebruik om die data te analiseer.

Die resultate dui daarop dat daar vir ' $n$ aantal vertikale, horisontale en omtrekmates nie internasionale beskrywings beskikbaar is nie, of dat daar nie ooreenstemming tussen die internasionale beskrywings is ten opsigte van hoe die mates geneem moet word nie. Resultate het ook aangedui dat vir veral die vertikale mates die respondente nie saamstem met betrekking tot hoe en waar die mates geneem moet word nie. Daar word ook probleme ondervind met die neem van die vertikale mates en omtrekmates. Die gebrek aan konsensus tussen die respondente se beskrywings van mates kan toegeskryf word aan ondermeer die gebrek aan internasionale riglyne. Dit het implikasies vir die neem van akkurate liggaamsmates en die maak van goedpassende patrone.

'n Wye verskeidenheid liggaamsmates word gebruik deur die Suid-Afrikaanse klere-industrie. Die gebrek aan konsensus, internasionaal sowel as plaaslik, is ' $n$ moontlike oorsaak vir die probleme wat ondervind word. Onvolledige beskrywings met betrekking tot die identifisering van landmerke, sowel as metodes waarvolgens die mates geneem moet word, behoort deur die industrie as geheel aangespreek te word.

\section{- Ms M Strydom}

Department of Consumer Science

University of Pretoria

- Prof HM de Klerk

Department of Consumer Science

University of Pretoria

\section{INTRODUCTION}

One of the most important consumer needs regarding clothing or apparel is that of well-fitting garments. Salusso-Deonier in Sieben and Chen-Yu (1992) states that consumers often use garment fit as a means of evaluating the quality of the garment. Brown and Rice (1998:39) agree with this view and state that fit affects comfort, as well as wear life of a garment. When a garment is ill-fitting, the consumer is dissatisfied, irrespective of the quality of the material or the workmanship, or the fashion ability of the garment (Winks, J, 1997). Ill-fitting garments will probably also have negative consequences for clothing retailers and manufacturers because the only true competitive advantage that the clothing industry has is keeping their present customers satisfied, since it is much more cost-effective for the retailer and manufacturer to retain loyal customers instead of seeking new customers all the time (Brown \& Rice, 1998:38).

Dissatisfaction with fit of women's ready-to-wear clothing is widely expressed, both in academic and popular literature (Anderson et al, 2001). The inability of the consumer to find satisfactory fit relates to the deviation of the human form from the standard pattern shape, as well as the great variety of human forms (Anderson et al, 2001). By improving the fit of garments, to be consistent with consumers' expectations and as a result improving the perceived quality of garments, clothing retailers and manufacturers can achieve a loyal customer base and expand their business at the same time (Brown \& Rice, 1998:38).

From the clothing retailer's and manufacturer's point of view it is not possible to address the consumer's problems with fit without a set of accurate body measurements (Istook \& Hwang, 2001). The ultimate success of any sizing system lies with the accuracy of body measurements (within a specified allowable error per specific measurement), since problems with fit often originate from outdated and inaccurate measurement data. Size charts currently in use provide outdated standards, which remain the basis for pattern development (Anderson et al, 2005) and this eventually leads to ill-fitting garments. It is assumed that the standards used by the industry in South Africa are also outdated. To be able to revise current standards used by the South African clothing industry, it is first necessary to obtain current measurements of the South African population. It is however important to consider which measurements are needed, and also exactly how they should be measured on the body, because, when designing for a market, it is necessary to have available reliable anthropometric data, otherwise the product (in the case of this study, apparel and shoes) may be totally unsuitable for the user (Ashby, 1978:4). Scientific garment cutting is based 
on measurements of the human form. The correct sesti 0378aztharoßam of key dimensions related to the specific product is vitally important. Various aspects can determine which key dimensions are required to manufacture certain garments, for example, who the garment is for and which part of the body is to be covered. Tamburrino (1992) explains, for example, that a tailored jacket may require at least six dimensions for construction, namely chest or bust girth, waist girth, seat girth, jacket length, sleeve length and waist length, while a men's dress shirt requires three dimensions - neck girth, shoulder girth and sleeve length. These measurements are the first steps towards drafting a correct pattern. Fit is determined by pattern making (Hudson, 1980), and pattern making starts with the body measurements.

The situation in South Africa, with its multi-cultural population, regarding sizing and fit is not different from anywhere else in the world. To be able to solve fit problems, it is however necessary to know how the industry functions with regard to providing well-fitting garments. The problem is that very little is known about how the South African clothing industry ensures well-fitting garments. The aim of this research (as part of a broader research project) was thus to explore and describe the problems that the South African clothing industry currently experiences with regard to body measurements needed for the manufacturing of wellfitting clothes.

\section{LITERATURE BACKGROUND}

One of the challenges that the apparel production and retail industry has to meet is to provide garments that will fit a three-dimensional human body form (Knight, 1994:1). According to Istook and Hwang (2001), it is not possible to address the consumer's problems with fit without a set of accurate body measurements. Body measurements are the basis for pattern construction (Workman, 1991). Pattern construction has a very important influence on the fit of the garment. Two bodies with the same dimensions but with different attributes may each require a different pattern (Tamburrino, 1992), because the same garment will not fit individuals with similar body measurements but different proportions equally well. Body measurements must therefore be considered together with proportions to enable a decent fit for different people. The apparel industry is moving toward more diversity by providing more choices and therefore should evaluate the basis of its sizing systems and develop new systems that would provide more consumers with better fit (LaBat \& DeLong, 1990).

Industry's effort to supply well-fitting garments is based on their sizing systems. In its simplest form a sizing system is a set of pre-determined body sizes designated in a standard manner (Winks, JM, 1997:24). A sizing system generates the size charts, which provide the measurements necessary for garment production (Kunick, 1984:9). Chun-Yoon and Jasper (1993) identified the problems with fit as the result of: (1) sizing systems being based on outdated appropriate sizes to accommodate the full range of variation in body types that exist in the current population. Very few sizing systems accommodate differences in body proportions related to age, ethnicity or body weight (Winks, J, 1997; Goldsberry et al, 1996; Giddings \& Boles, 1990). One of the problems encountered when designing for people, especially in South Africa with its multi-cultural population, is that they are different; for instance, tall or short, slim or fat, long arms, short legs, big heads, small feet, young or old (Ashby, 1978:1). This can be overcome if the variation in the size of a population is given due consideration. It is the function of a sizing system to establish limits regarding the variability of sizes. Current sizing systems do not adequately address these variations. Current sizing systems are based on the principle that the difference between sizes is measurable in equal linear distances. Linear increments between sizes in a sizing system facilitate pattern-making and grading. Actual human measurements, however, do not support the assumption that the difference between the principal girths is constant (Schofield in Desmarteau, 2000). It is clear that how and where these measurements should be measured on the human body must be described in detail to be able to make accurate assumptions and comparisons.

The selection of key dimensions to develop sizing systems offers another problem. Key dimensions are measurements that serve as predictors of the sizes of other parts of the body (Chun-Yoon \& Jasper, 1996). A key dimension is a body dimension that has a strong relationship with most other body dimensions that are important to the garment. According to Winks (1990:22), the correlations among relevant body measurements are critical in the manufacture of bodyfitting garments. Key dimensions are fundamental to the definition of body size and are used to assign an appropriately sized garment for a wearer (Winks, JM, 1997:24), it is therefore critical for fit that one is exactly sure how and where these key dimensions should be measured on the human body. For consistency in sizing it is also important that the key dimensions be measured in a standardised way by all manufacturers and retailers.

It is important that these measurements be current, accurate and representative for the population for which the sizing system is being developed. Ashdown (2002) states that population measurements can be used to determine the range (smallest to largest), as well as the variation (differences in proportions) of the people in a population. Population measurements are especially important in countries where variations are the result of the population consisting of a variety of ethnic groups, as is the case in South Africa. If population measurements are outdated and inaccurate for a specific population, the best sizing system will not be able to ensure well-fitting garments for that population.

Measurements can be obtained by different methods, namely traditional tailor's measurements, traditional anthropometry or three-dimensional body scanning. 
The accuracy as well as the representativeness of the population's measurements may be influenced by the measuring methods used, equipment calibration and the measurer's expertise. It is therefore necessary to briefly discuss the different measuring methods.

Traditional tailor's measurements refer to measurements taken by hand using a measuring tape. Measurements taken and landmarks are directly related to the garments that are to be made. Most measurements are taken along the contours of the body and not in a straight line between two points. Due to the variability in identifying landmarks and the placement of the measuring tape on the body by different measurers, it is not always possible to repeat measurements. The accuracy of traditional tailor's measurements (within a specified allowable error per specific measurement) can be significantly reduced as a result of posture shifts by the person being measured. Although a skilled tailor or dressmaker can take very accurate measurements, methods and measurements can vary considerably among different professionals (Ashdown, 2002).

Anthropometry literally means the measurement of people (Norgan in Ulijaszek \& Mascie-Taylor, 1994:141). It can be defined as the science of measurement. It deals with measurements of the physical characteristics of human beings - particularly their sizes and shapes (Pheasant, 1996:3; Norgan in Ulijaszek \& Mascie-Taylor, 1994:141). Anthropometric measurement methods and tools have been developed to make valid and reliable measurements of individuals in a population possible. Anthropometric tools include anthropometers (a standing tool that measures straight linear distances), callipers (measures linear depths and widths), and calibrated measuring tapes (Ashdown, 2002). Observer error is the most troublesome source of anthropometric error and includes imprecision in landmark location, subject positioning and instrument applications (Simmons \& Istook, 2003). Accuracy (within a specified allowable error) is therefore, amongst others, dependent on the person taking the measurements. It is often advised that two persons should separately measure each subject to ensure the least amount of error. Careful and accurate location and marking of landmarks on the body, as well as proper training of personnel can ensure consistency and accuracy of measurements. It is clear that the collection of anthropometric data is a time-consuming and expensive process that requires skilled personnel.

The development of three-dimensional body scanners has opened up new possibilities for the measurement and analysis of the human body (Ashdown, 2002). In recent years, researchers have developed threedimensional body scanners that can capture the outside surface of the human body within a few seconds by using optical techniques. This measurement technique can be non-contact, instant and accurate through the use of laser light or white light and cameras. This technology has the potential to enable researchers to collect and process more accurate anthropometric data than ever before almost instantane- ously (Le Pechoux \& Ghosh, 2002). Threedimensional scanning produces a 360 degree replica of the human body on a dimensionally accurate computer screen. This image of the human body can be stored and then viewed, rotated, sliced and measured on the computer by using automated measuring procedures whenever information is needed. This makes it possible to analyse body postures and proportions in new ways (Ashdown, 2002). Unfortunately, there are still some shaded body areas that cannot be scanned effectively. For the time being, three-dimensional body imaging has to be used in conjunction with manual measurement.

Unfortunately, three-dimensional body scanners are not yet available in South Africa for use by the clothing industry. In general, measurements are taken in the traditional tailor's manner with ordinary tape measures. It is therefore very difficult to compare measurements used by different companies because of the variation in measurements and methods used by different professionals. Anthropometric surveys have been undertaken in the past, but because of the time and financial implications involved, the number of measurements are limited. These measurements are also not available for use by everybody involved in the clothing industry, but are restricted to the companies doing the surveys. The use of a three-dimensional body scanner can make body measurement surveys more accessible to the clothing industry in general. Using less time to scan one person it might be possible to obtain more measurements from more people in the same time that a traditional anthropometric survey would take to complete. Therefore it would be ideal to undertake such a survey by using a 3D-body scanner. It is, however, necessary to establish how and where measurements are to be taken on the body to ensure that critical and useful measurements are obtained.

As very little is known about how the South African clothing industry functions with regard to the taking of body measurements, as well as the problems that they experience with regard to body measurements, the specific research aims of this research were:

- To compare international descriptions of all identified body measurements needed by the South African clothing industry, with the South African respondents' descriptions of the identified body measurements.

- To describe the problems that the South African clothing industry experience with body measurements.

\section{METHODOLOGY}

The research problem was addressed by collecting new or primary data and by analysing existing or secondary data. The scope of the objectives of this study necessitates a quantitative research paradigm. Quantitative data collection techniques have been applied to adequately address the research problem and objectives. To identify the body measurements required by South African apparel and footwear manufacturers and retailers, a representative postal survey was con- 


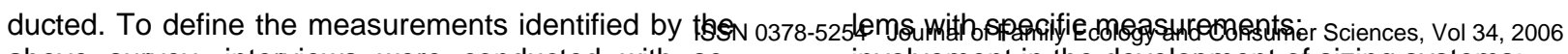
above survey, interviews were conducted with selected manufacturers and retailers individually.

- involvement in the development of sizing systems;

- number of years in business.

\section{Sampling}

The target population for this study was South African apparel and footwear manufacturers and retailers. The sampling frame was defined as clothing manufacturers and retailers listed in the Clothing Federation of South Africa Handbook (2000/1). For footwear and accessories the Shoes and Views Directory (2001) was consulted. These lists of manufacturers were chosen because they give an indication of which type of garment or shoe is manufactured.

In South Africa, as elsewhere in the world, product development is retail-driven. Because of the prescriptive relationship existing between retailers and manufacturers, the major retail chains were included in the target population. Chain stores are a group of stores that sell essentially the same merchandise and are centrally owned, operated and merchandised (Frings, 1999:362). It is assumed that the smaller chains and boutiques are too small to influence the sizing systems used by manufacturers. Furthermore it is assumed that smaller retailers will have to follow the lead of the major chains to survive in the competitive clothing and footwear retail environment. This view is supported in a report by Dunne (2000). A combined list of retailers was obtained from the Clofed Handbook (2000/1) and Shoes and Views Directory (2001). For this study, only national retailers of both clothing and footwear products were included. Manufacturers for the footwear industry and figure form manufacturers for the clothing industry are also important users of body measurements and therefore formed part of the target population for this study.

After consultation with the statistician it was decided to include the entire target population in the study. This is mainly due to the fact that a postal survey was conducted and the response rate for postal surveys is often poor. The lists of manufacturers and retailers were consolidated and a total number of 472 respondents were identified. From the manufacturers and retailers that responded to the postal survey and returned completed questionnaires, a purposive or judgemental sample was taken for the interviews. This means that the sample was selected based on the researcher's judgement and the purpose of the study. Since the number of responses to a postal survey may be low, this sampling technique ensured a representative sample for the interviews. According to Kvale (1996:102), the number of interviews in current interview studies tends to be around 10 to 15 . For this study, 12 companies were chosen to be interviewed. Parameters for selection of this second sample included the following:

- geographical area;

- manufacturers and retailers covering the whole spectrum of garment categories;

- manufacturers and retailers catering for specific figure requirements;

- manufacturers and retailers that indicated prob-

\section{Data collection methods}

Since the objective with the postal survey was to identify body measurements that are used by the clothing industry, the closed question questionnaire seemed appropriate. According to Neuman (2000:261), closed questions are also easier and quicker for respondents to answer. This is an important consideration as time is of the essence in the clothing and footwear industries.

Response rates are a big concern in postal survey research (Neuman, 2000:266). Because the survey was followed by an interview, the researcher kept a complete and accurate record of questionnaires posted and returned. Confidentiality was guaranteed, although the survey was not anonymous. Nonresponses were followed-up with phone calls and where necessary a second questionnaire was sent, either by post or in most cases by e-mail. The above strategies were followed to achieve a better response rate. Although the response rate was still poor $(17,5 \%)$, it was better than expected according to the statistician's prediction, namely $10 \%$.

The questionnaire was developed by identifying measurements as contained in local and international documentation, such as published by the International Standards Organisation (ISO), American Society for Testing and Materials (ASTM) and South African Bureau of Standards documents (SABS) (refer to Strydom, 2006:38-39 for full list). Body dimensions that were included in the Nedscan (2001) (Dutch part of the CEASAR project) and SizeUK (2000) anthropometric surveys were also considered for inclusion in the questionnaire.

The comprehensive questionnaire included all the possible measurements and was sent to the clothing manufacturers producing all types of clothing and to the retailers. To ensure quick and easy completion of the questionnaire, the questionnaires for the different categories of manufacturers contained only relevant body measurements. The questionnaires for headwear, gloves and footwear included only measurements concerning these specific areas of the body. The questionnaire was reviewed by an expert in the clothing industry as recommended by Fink (1995:25). Following this expert's recommendation, figures indicating the positions of the body dimensions were included in the questionnaire to enhance the clarity of the questionnaire.

In order to ensure accurate definitions of the identified measurements the individual interview was identified as an appropriate technique. To ensure reliability of the data, the interviews were conducted with the following persons: production managers, quality assurance managers, technical managers, fit technologists, garment technologists, and designers/pattern makers. It was considered that one interview per respondent 
would be sufficient. A structured interview schedule was used to ensure that all the topics were covered during the interview. The topics to be discussed during the interview were chosen in accordance with the conceptual framework and the objectives of the study.

In the industry, taking measurements are in most cases not based on theoretical knowledge of the definitions of the measurements but on years of experience. It is not always easy to describe or explain how and where measurements are taken. The interview technique provided the respondent with the opportunity to demonstrate how measurements are taken rather than providing mere descriptions. The interviewer was then able to observe how and where a specific measurement is taken. To prevent any information from being lost or missed during the interview, audiotapes were kept and notes were taken where possible during the interview. Audiotapes were made with the respondents' permission in order to preserve the original data and to confirm the credibility of the data. The descriptions provided by the respondents were compared to descriptions from the documentation discussed earlier.

\section{Data analysis}

The data obtained from the postal survey were analysed to identify all the measurements needed for the different garment types, as well as to identify problematic measurements. This was done with the use of descriptive statistics in the form of frequency tables. It was possible to compile a list of all the body measurements that should be included in a South African anthropometrical database to ensure that it is representative of the clothing and footwear industries. The purpose was not to understand or explain the choice of body measurements by industry, but simply to identify all the measurements used. Frequency tables gave a complete overview of collected data and seemed sufficient for this stage of the research. It also assisted in the identification of respondents who have been in business for a longer period of time, and who are involved in the development of sizing systems and provide for special figure requirements. These aspects were important considerations in the sampling for the interviews.

The transcriptions of the interviews, together with notes taken during the interviews and documents received from some of the respondents, were analysed by means of content analysis. A quantitative analysis was then done on a spreadsheet, to determine the frequency with and the context in which the themes occurred.

\section{RESULTS AND DISCUSSIONS}

Table 1 illustrates the total number of international identified measurements for which descriptions exist as international level. It also reflects on the existence of international, national, as well as internationalnational consensus with regard to how the measurement should be taken. The percentage of cases where problems with regard to the taking of the measurements were reported, and whether these problems were related to the measurements being taken on the contours of the body or in a straight line next to the body, problems with landmarking, and landmarking together with a lack of consensus on the measurement definition, is also indicated in the table.

Comparison of international measurement descriptions with South African descriptions and problems experienced in the South African clothing industry with regard to vertical height measurements

It is clear from Table 1 that for nearly one third $(29,1 \%)$ of the vertical height measurements there are either no international descriptions available or no consensus among the international descriptions as to how the measurements should be taken $(22,2 \%+$ $6,9 \%$ ). Although descriptions are available for $77,8 \%$ of the vertical height measurements, for more than two thirds (68\%) of the international descriptions it was not possible to come to a conclusion regarding consensus due to the fact that only one description was available or no description at all. It should further be noted that in the case of a large proportion of the vertical height measurements $(40,3 \%)$, the respondents do not agree how and/or where the measurement should be taken. With regard to consensus between the international and the respondents' descriptions, it is clear that there seems to be consensus between the international and the respondents' descriptions in only less than half of the vertical height measurements. Since international descriptions are available for $77,8 \%$ of the vertical height measurements, this result clearly shows that the respondents do not always agree with international descriptions. It may also be an indication that the international description is vague and not clearly described which may lead to confusion and a different interpretation of the description by the respondents. This has definite implications for the taking of consistent and accurate measurements, which further impacts on the drafting of well-fitting patterns.

Respondents experience problems with $66,7 \%$ of the vertical height measurements. Such a large proportion of problem measurements can only predicate problems with the sizing of clothing items. It is, however, a good sign that the respondents admit to having problems with the body measurements. It implies that the respondents from the industry probably value and strive for accurate body measurements, which highlights the need for a body measurement survey of the South African population. It is also clear that the problems are mostly related to landmarking, and also whether measurements should be taken in a straight line or along the contours of the body. This has important implications for taking accurate body measurements and drafting well-fitting patterns. Once again, the importance of having clear and detailed descriptions about the identification of landmarks and measuring techniques is highlighted.

Comparison of international measurement descriptions with South African descriptions and problems 


\begin{tabular}{|c|c|c|c|c|c|c|c|c|}
\hline & 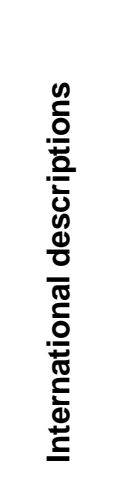 & 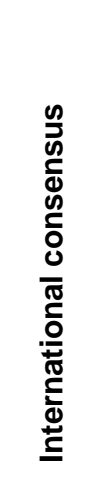 & 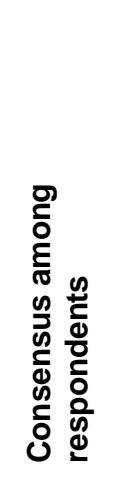 & 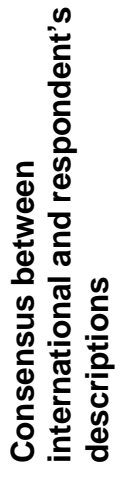 & $\begin{array}{l}\frac{n}{0} \\
\frac{0}{0} \\
\frac{0}{0}\end{array}$ & 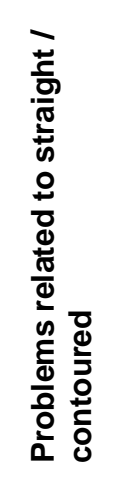 & 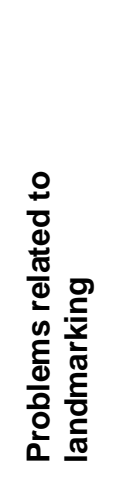 & 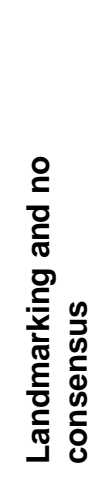 \\
\hline \multicolumn{9}{|c|}{ Vertical height measurements } \\
\hline Yes & $\begin{array}{c}56 \\
77,8 \% \\
\end{array}$ & $\begin{array}{c}18 \\
25,0 \% \\
\end{array}$ & $\begin{array}{c}38 \\
52,8 \% \\
\end{array}$ & $\begin{array}{c}34 \\
47,2 \% \\
\end{array}$ & $\begin{array}{c}48 \\
66,7 \% \\
\end{array}$ & $\begin{array}{c}28 \\
38,9 \% \\
\end{array}$ & $\begin{array}{c}50 \\
69,4 \% \\
\end{array}$ & $\begin{array}{c}23 \\
31,9 \% \\
\end{array}$ \\
\hline No & $\begin{array}{c}16 \\
22,2 \% \\
\end{array}$ & $\begin{array}{c}5 \\
6,9 \% \\
\end{array}$ & $\begin{array}{c}29 \\
40,3 \% \\
\end{array}$ & $\begin{array}{c}21 \\
29,2 \% \\
\end{array}$ & $\begin{array}{c}24 \\
33,3 \% \\
\end{array}$ & $\begin{array}{c}43 \\
59,7 \% \\
\end{array}$ & $\begin{array}{c}21 \\
29,2 \% \\
\end{array}$ & $\begin{array}{c}48 \\
66,7 \% \\
\end{array}$ \\
\hline Conclusion not possible & $\begin{array}{c}0 \\
0,0 \%\end{array}$ & $\begin{array}{c}49 \\
68,0 \%\end{array}$ & $\begin{array}{c}5 \\
6,9 \% \\
\end{array}$ & $\begin{array}{c}17 \\
23,6 \% \\
\end{array}$ & $\begin{array}{c}0 \\
0,0 \%\end{array}$ & $\begin{array}{c}1 \\
1,4 \%\end{array}$ & $\begin{array}{c}1 \\
1,4 \%\end{array}$ & $\begin{array}{c}1 \\
1,4 \%\end{array}$ \\
\hline Total & 72 & 72 & 72 & 72 & 72 & 72 & 72 & 72 \\
\hline \multicolumn{9}{|c|}{ Width and depth measurements } \\
\hline Yes & $\begin{array}{c}17 \\
100,0 \\
\%\end{array}$ & $\begin{array}{c}3 \\
17,6 \%\end{array}$ & $\begin{array}{c}12 \\
70,6 \%\end{array}$ & $\begin{array}{c}11 \\
64,7 \%\end{array}$ & $\begin{array}{c}15 \\
88,2 \%\end{array}$ & $\begin{array}{c}2 \\
11,8 \%\end{array}$ & $\begin{array}{c}12 \\
70,6 \%\end{array}$ & $\begin{array}{c}4 \\
23,5 \%\end{array}$ \\
\hline No & $\begin{array}{c}0 \\
0,0 \%\end{array}$ & $\begin{array}{c}3 \\
17,6 \% \\
\end{array}$ & $\begin{array}{c}5 \\
29,4 \% \\
\end{array}$ & $\begin{array}{c}6 \\
35,3 \% \\
\end{array}$ & $\begin{array}{c}2 \\
11,8 \% \\
\end{array}$ & $\begin{array}{c}15 \\
88,2 \% \\
\end{array}$ & $\begin{array}{c}5 \\
29,4 \% \\
\end{array}$ & $\begin{array}{c}13 \\
76,5 \% \\
\end{array}$ \\
\hline Conclusion not possible & $\begin{array}{c}0 \\
0,0 \%\end{array}$ & $\begin{array}{c}11 \\
64,7 \%\end{array}$ & $\begin{array}{c}0 \\
0,0 \%\end{array}$ & $\begin{array}{c}0 \\
0,0 \%\end{array}$ & $\begin{array}{c}0 \\
0,0 \%\end{array}$ & $\begin{array}{c}0 \\
0,0 \%\end{array}$ & $\begin{array}{c}0 \\
0,0 \%\end{array}$ & $\begin{array}{c}0 \\
0,0 \%\end{array}$ \\
\hline Total & 17 & 17 & 17 & 17 & 17 & 17 & 17 & 17 \\
\hline \multicolumn{9}{|c|}{ Circumference measurements } \\
\hline Yes & $\begin{array}{c}28 \\
93,3 \%\end{array}$ & $\begin{array}{c}17 \\
56,7 \% \\
\end{array}$ & $\begin{array}{c}14 \\
46,7 \% \\
\end{array}$ & $\begin{array}{c}12 \\
40,0 \%\end{array}$ & $\begin{array}{c}8 \\
26,7 \% \\
\end{array}$ & $\begin{array}{c}0 \\
0,0 \%\end{array}$ & $\begin{array}{c}18 \\
60,0 \%\end{array}$ & $\begin{array}{c}12 \\
40,0 \% \\
\end{array}$ \\
\hline No & $\begin{array}{c}2 \\
6,7 \% \\
\end{array}$ & $\begin{array}{c}6 \\
20,0 \% \\
\end{array}$ & $\begin{array}{c}14 \\
46,7 \% \\
\end{array}$ & $\begin{array}{c}16 \\
53,3 \% \\
\end{array}$ & $\begin{array}{c}22 \\
73,3 \% \\
\end{array}$ & $\begin{array}{c}30 \\
100,0 \% \\
\end{array}$ & $\begin{array}{c}12 \\
40,0 \% \\
\end{array}$ & $\begin{array}{c}18 \\
60,0 \% \\
\end{array}$ \\
\hline Conclusion not possible & $\begin{array}{c}0 \\
0,0 \% \\
\end{array}$ & $\begin{array}{c}7 \\
23,3 \% \\
\end{array}$ & $\begin{array}{c}2 \\
6,7 \% \\
\end{array}$ & $\begin{array}{c}2 \\
6,7 \% \\
\end{array}$ & $\begin{array}{c}0 \\
0,0 \% \\
\end{array}$ & $\begin{array}{c}0 \\
0,0 \% \\
\end{array}$ & $\begin{array}{c}0 \\
0,0 \% \\
\end{array}$ & $\begin{array}{c}0 \\
0,0 \% \\
\end{array}$ \\
\hline Total & 30 & 30 & 30 & 30 & 30 & 30 & 30 & 30 \\
\hline
\end{tabular}

experienced in the South African clothing industry with regard to width and depth measurements

The 17 horizontal measurements are divided in width and depth measurements and circumferences. The width measurements are taken in a straight horizontal line, from side to side, from the front or the back of the body. Note that the width measurements differ from the arc measurements which are taken from "side seam" to "side seam". The depth measurements are taken in a straight horizontal line, from front to back, from the side of the body. The terms from side to side or front to back used in the width and depth measurements refer to the outline or silhouette of the body. The circumference measurements, also referred to as girths, are measured horizontally around the body, starting and ending at the same position. Width and depth measurements are not always directly used for pattern making or garment construction, but they are needed in order to analyse the shape of the body. These measurements can give an indication of how a circumference measurement is distributed around the body. Therefore the width measurements are particularly important for the manufacturing of fit dummies.

With regard to the availability and consensus of internationally accepted descriptions it is clear that such descriptions were found for all the width and depth measurements that were included in this study. In $64,7 \%$ of the cases there was only one description available and therefore a conclusion regarding consensus was not possible. For the cases where there were more than one description, consensus was found in only half of the cases $(17,6 \%$ of a total of $35,2 \%$ cases with more than one description).

It seems that there is a higher level of agreement among the respondents on how the width and depth measurements should be taken, although it should be noted that in $29,4 \%$ of the cases there were still no agreement as to how the measurements should be taken. Since international descriptions are available 
for $100 \%$ of the horizontal width and depth measurements, one might have expected a higher level of consensus among the international and the respondents' descriptions. Again, as with the vertical height measurements, this result clearly shows that the respondents do not always agree with international descriptions.

Although international descriptions are available for all these measurements and a high level of consensus among the respondents' descriptions exist, problems are experienced with $88,2 \%$ of the measurements. This may have major implications for the manufacturing of well-fitting clothes that fit the shape and size of the South African consumer, since the horizontal width and depth measurements are important indicators of body shape. Again, the fact that the respondents recognise problems with such a large number of width and depth measurements indicates an interest in, and a need for clear descriptions of body measurements as well as accurate body measurement data. Bougourd (2004:10) states that retailers used the SizeUK survey to gain a better understanding of their customers' shapes and sizes, and it seems that the same need exists among the respondents of this study. It is therefore important that a database of current and accurate South African population measurements is established. This can only be done if detailed and standard measurement descriptions are available. As in the case of the vertical measurements, most of the problems are related to landmarking. This has important implications for taking accurate body measurements and drafting well-fitting patterns. This again highlights the importance of clear descriptions for recognisable landmarks.

\section{Comparison of international measurement de- scriptions with South African descriptions and problems experienced in the South African cloth- ing industry with regard to circumference meas- urements}

Considering the importance of the 30 girth measurements with regard to the sizing of garments, as well as for pattern drafting, it should be noticed that for $26,7 \%$ of the circumferences there are no consensus or no descriptions available internationally $(20,0 \%+6,7 \%)$. Respondents agreed on how and where the measurements should be taken in the case of only $46,7 \%$ of the measurements. Because of the importance of these measurements one would have expected a much higher level of consensus among the respondents' descriptions. Uncertainty or confusion about taking the circumference measurements can only predicate chaos with the fit and sizing of garments.

It should further be noted that consensus among the international and the respondents' descriptions only exists for less than half of the circumference measurements. Since international descriptions are available for $93,3 \%$ of the circumference measurements, this result clearly shows that the respondents do not always agree with the international description of a measurement. It can also be an indication that the international description is vague and not clearly de- scribed which leads to confusion and a different interpretation of the description by the respondents.

Problems are only experienced with $26,7 \%$ of the circumference measurements. One would have expected more of the measurements to be regarded as problem measurements, since there is no consensus and no international descriptions for $60,0 \%$ of the circumference measurements. The low number of problems experienced is not supported by the $60 \%$ of measurements with landmarking problems and $36,7 \%$ of measurements with problems related to landmarking together with no consensus reached. This could be an indication of ignorance or a "don't care" attitude towards problems with the circumference measurements. Another explanation could also be that, because the circumference measurements are commonly used everyday in the clothing industry, it could be that the problems with the measurements are so well-known and solutions for coping have been established, and therefore the measurements are not seen as problem measurements.

It is thus clear that the taking of vertical measurements is problematic among the respondents. This may be due to the fact that in $22,2 \%$ of cases there are no international descriptions available and for a further $6,9 \%$ there is no international consensus with regard to the descriptions. If one assumes that South African retailers and manufacturers probably rely on international standards, one can understand the uncertainty in the industry as to where and how the measurements should be taken. This uncertainty is reflected in the $52,8 \%$ of cases with consensus among respondents, which is just more than half of the measurements, and in consensus among respondents and international descriptions for less than half of the measurements (47,2\%). One would expect, and in fact require, a much higher rate of consensus in order to ensure consistency and accuracy of measurements.

The highest percentage of problem measurements was however experienced with the taking of width and depth measurements. This was in spite of the fact that international descriptions are available for all measurements. To be able to take the width and depth measurements consistently and accurately, special equipment is necessary which the respondents do not necessarily have.

The taking of circumference measurements was the least problematic among the respondents. This was in spite of the fact that in $26,7 \%$ of cases there were no international descriptions available or no international consensus with regard to the descriptions. Again, if one assumes that South African retailers and manufacturers probably rely on international standards, one would expect a much higher number of problems regarding the taking of the circumference measurements. A high level of uncertainty is however reflected in the $46,7 \%$ of measurements with consensus among respondents, which is less than half of the measurements, and in consensus between respondents' and international descriptions, also for less than half of the measurements (40\%). One would expect, and in fact 
require, a much higher rate of consensus in order to ensure consistency and accuracy (within a specified allowable error per specific measurement) of measurements, especially because of the importance of the circumference measurements. It is clear that the circumference measurements are more problematic than the respondents were willing to admit.

\section{Factors contributing to problems experienced with the taking of measurements}

From the interview responses it was also clear that the problems that the respondents experienced, and/or the fact that there was no consensus between the respondents' and international descriptions, were due to the following facts. These aspects were not specifically measured but were identified during the analysis of the interview transcriptions, and are presented in no specific order of importance.

- It was a difficult measurement to take (as in the case of crotch length, for instance)

- The international description was not clear with regard to the landmarking - exactly where and how the landmark should be determined (as in the case of armscye depth, for instance)

- Uncertainty with regard to whether the measurement should be taken on the contour of the body or in a straight line (as in the case of cervical height, for instance)

- The unavailability of the necessary anthropometric tools (as in the case of neck width, for instance)

- The unavailability of actual data on some measurements (as in the case of most of the hand and foot measurements.

These results indicate that the lack of consensus concerning body measurements is probably the cause of most of the problems that are being experienced. A study by Hwang and Istook (2001) also found a lack of consensus in terminology and acceptance of standard measurements for apparel. They found that traditional body measurement methods for apparel have been based on "feel by hand". This is also true for the respondents of this study, since measurements are taken with a tape measure. It is therefore important for the measurer to be trained to know what he or she is feeling even on fuller figures where important landmarks are covered. The importance of consistently being able to identify landmarks was repeatedly emphasised by the respondents. This was seen as a very important influence on whether the accuracy of the data could be trusted. There seemed to be a definite need for as much as possible information on the body measurements of South African consumers. It is of vital importance to potential industry users that measurement definitions be absolute and repeatable, so that they can be used very accurately for customisation and production activities (Simmons \& Istook, 2003). Landmarking was identified as a problem with a number of measurements and this problem needs to be addressed, not only by the local industry but also internationally.

Hwang and Istook (2001) also found that different methods and definitions add to the lack of consensus,
0378 for instance whether arm length should be measured $) 6$ with a bent or straight arm and from different landmarks, and that imaginary lines such as "side seam to side seam" were very vague descriptions. A similar situation was found in this research, where an important discrepancy between the international and the respondents' descriptions was the issue of measuring either along the contours of the body or in a straight line. This has important implications for the fit of garments, since contoured measurements could assist in defining the body shape to the pattern maker. For patternmaking purposes, it is important to have actual measurements taking the contours into consideration, but also to have straight measurements as a control in order to apply the measurements correctly to the pattern. It is, however, difficult to take contoured body measurements accurately. It is important that consensus be reached on the method used for taking the measurements, for instance whether arm length should be taken from a bent or a straight arm. One of the requirements that Tamburrino (1992) therefore sets for anthropometrical data to be of practical use, is that the data must satisfy the technical requirements of the clothing industry. This would imply that measurements should be taken according to uniform and standard criteria. In order to increase efficiency in CAD garment sizing, pattern development and the alteration process as Hwang and Istook (2001) suggest, it is therefore critical that the clothing industry in South Africa reach consensus on their preferred measuring methods.

\section{CONCLUSIONS AND RECOMMENDATIONS}

The overall conclusion that can be drawn is that a wide variety of measurements are used in the South African clothing industry and that major problems exist with the taking of measurements - probably resulting in consumers' current dilemma of not being able to find well-fitting clothes.

These problems may be due to a lack of clear descriptions as to how and where on the body the measurements should be taken, but may also be due to a "don't care" or "everybody knows" attitude in the industry. Problems may also be due to a lack of standardized anthropometric measuring equipment which, if solved, can in some cases ensure higher accuracy. However, many of the problem measurements are difficult to measure, either because of difficulties to establish landmarks, or difficulties and uncertainty as to how and where on the body the measurement should be taken.

The fact remains that many retailers and manufacturers experience problems with the taking of measurements, and bearing in mind the high percentage of cases where there is no national-international consensus or no consensus amongst South African respondents as to how and where the measurements should be taken, one would have expected the rate for reported problems to be even higher. What makes the situation worse is that many of these problems seem to be experienced with the taking of key dimensions 
which can only spell trouble for the designing and manufacturing of well-fitting clothes.

In order to ensure well-fitting garments and good fit in general, it is of the utmost importance that manufacturers and retailers should have a sound knowledge on exactly how and where on the body the various measurements should be taken, and should have and use the equipment that will enable them to consistently take accurate measurements. It is also important that the industry address the problem of consensus with regard to landmarking and measuring method, and that they reach consensus on which landmarks are to be used, describe in detail how these landmarks can be identified consistently, and agree on the method for taking body measurements.

Retailers have to redefine their focus and take cognisance of customer demand for better quality (Dunne, $2000: 23$ ). As a result of increasing competition in the clothing-retail sector and in order to be competitive with Eastern markets, it is important for retailers and manufacturers to improve fit because better quality is the only way to stay competitive (Dunne, 2000:9,10). The importance of accurate and current body measurements can therefore no longer be ignored and the problem should urgently be addressed by the local industry.

It can finally be concluded that it is imperative and urgently required that a body measurement survey of the South African population be undertaken. Retailers and manufacturers in the UK have experienced the value of the SizeUK survey by, amongst others, revealing a reduction in returns. Using accurate and current body measurement data and understanding the relationship of body shape and size, had definite advantages for retailers and manufacturers in the UK, commercially as well as by enhancing customer satisfaction (Bougourd, 2004). With the development of 3D body scanning, the existence of an accurate and current data set of the body measurements and size and shape of South African consumers is not just wishful thinking anymore. With 3D body scanning human error is greatly reduced, resulting in the survey data being more comparable and reproducible. Definition of landmarks and clear descriptions of measurements are, however, still a very important requirement to ensure comparability and reproducibility of any body survey, regardless of which measurements method is used. The success of such a project depends heavily on the involvement and support of retailers and manufacturers. It is therefore recommended that the clothing industry becomes involved and support the establishment of a database of South African body measurements.

\section{REFERENCES}

ANDERSON, LJ, BRANNON, EL \& PITTMAN, JF. 2005. Understanding fitting preferences of female consumers. [WWWdocument - 18/01/2005]. URL http://www.ntcresearch.org/current/year9/198-A08.htm ANDERSON, LJ, BRANNON, EL, ULRICH, PV,
PRESLEY, AB, WORONKA, D, GRASSO, M \& STEVENSON, D. 2001. Understanding fitting preferences of female consumers: development of an expert system to enhance accurate sizing selection. National Textile Center Annual Report: November 2001. 198A08.

ASHBY, P. 1978. Ergonomics handbook 1: Human factors design data. Body size and strength. Pretoria. Tute Publication.

ASHDOWN, SP. 2002. Sizing systems. [WWWdocument - 07/06/2002]. URL http:// www.human.cornell.edu/txa/faculty/SizingSystems BOUGOURD, J. 2004. The shape we're in: a survey of consumer body measurements in the UK. Consumer Sciences Today 5(4):10-11.

BROWN, P \& RICE, J. 1998. Ready-to-wear apparel analysis. Upper Saddle River. Prentice-Hall.

CHUN-YOON, J \& JASPER, CR. 1993. Garmentsizing systems: An international comparison. International Journal of Clothing Science and Technology 5 (5):28-37.

CHUN-YOON, J \& JASPER, CR. 1996. Key dimensions of women's ready-to-wear apparel: Developing a consumer size-labeling system. Clothing and Textiles Research Journal 14(1):89-95.

CLOFED HANDBOOK. (2000/1). The South African Clothing Industry. Bedfordview. Clothing Federation of South Africa.

DESMARTEAU, K. 2000. Let the fit revolution begin. Bobbin 41(10):1-10.

DUNNE, N. 2000. Understanding the South African clothing manufacturing sector from the perspective of leading South African clothing retailers. Research report No 31. Industrial Restructuring Project. School of Developmental Studies. University of Natal. Durban.

FINK, A. 1995. How to ask survey questions. (The Survey Kit, vol. 2). London. Sage.

FRINGS, GS. 1999. Fashion from concept to consumer. $6^{\text {th }}$ edition. Upper Saddle River. Prentice-Hall.

GIDDINGS, VL \& BOLES, JF. 1990. Comparison of the anthropometry of black males and white males with implications for pants fit. Clothing and Textiles Research Journal 8(3):25-28.

GOLDSBERRY, E, SHIM, S \& REICH, N. 1996. Women 55 years and older: Part II. Overall satisfaction and dissatisfaction with the fit of ready-to-wear. Clothing and Textiles Research Journal 14(2):121132.

HUDSON, PB. 1980. The role of fit and fashion in apparel quality. Bobbin 21(11):108-122.

HWANG, S \& ISTOOK, CL. 2001. Body measurement terminology used in the apparel industry. Paper presented at the 2001 KSCT/ITAA Joint World Conference. Seoul, South Korea.

ISTOOK, CL \& HWANG, S. 2001. 3-D body scanning systems with application to the apparel industry. Journal of Fashion Marketing and Management 5(2):120132.

KNIGHT, AL. 1994. The market feasibility of body scanning and size prediction technologies at retail. Unpublished Masters thesis. University of North Carolina.

KUNICK, P. 1984. Modern sizing and pattern making for women's and children's garments. London. Philip 
Kunick.

KVALE, S. 1996. An introduction to qualitative research interviewing. London. Sage.

LABAT, K \& DELONG, M. 1990. Body cathexis and satisfaction with fit of apparel. Clothing and Textiles Research Journal 8(2):43-47.

LE PECHOUX,B \& GHOSH, TK. 2002. Apparel sizing and fit. Textile Progress. 32(1):1-59.

NEDSCAN BODY MEASURES [WWW document 11/07/2001]. URL http://www.nedscan.nl/nedscan/ maatuk.htm (Dutch part of the CEASAR project).

NEUMAN, WL. 2000. Social research methods. Qualitative and quantitative approaches. $4^{\text {th }}$ edition. London. Allyn \& Bacon.

PHEASANT, ST. 1996. Anthropometrics. An introduction for schools and colleges. London. British Standards Institution.

SHOES AND VIEWS DIRECTORY. 2001. S\&V. The complete shoe, leather and fashion accessories trade magazine for Southern and Eastern Africa 64(5):1747.

SIEBEN, WA \& CHEN-YU, HJ. 1992. The accuracy of size information on men's pre-washed jeans. Clothing and Textiles Research Journal 11(1):74-82.

SIMMONS, KL \& ISTOOK, CL. 2003. Body measurement techniques. Comparing $3 \mathrm{D}$ body-scanning and
037 anthropometric methods for apparel applications. 6 Journal of Fashion Marketing and Management 7 (3):306-332.

SizeUK. 2000. 3D scanner technology survey and proofing. Centre for 3D electronic commerce. University College of London.

STRYDOM, M. 2006. An evaluation of South African clothing related population measures and sizing systems. Masters dissertation. University of Pretoria. Pretoria.

TAMBURRINO, N. 1992. Apparel sizing issues, part 2. Bobbin 33(9):52-60.

ULIJASZEK, SJ \& MASCIE-TAYLOR, CGN. (Eds). 1994. Anthropometry: the individual and the population. Cambridge. University Press.

WINKS, J. 1997. A fitting system for clothes - which size 12 are you? The Home Economist 16(1):4-6.

WINKS, JM. 1990. The development of standard sizing systems for clothes. MSc thesis. University of Port Elizabeth.

WINKS, JM. 1997. Clothing sizes. International standardization. Manchester. Redwood Books.

WORKMAN, JE. 1991. Body measurement specifications for fit models as a factor in clothing size variation. Clothing and Textiles Research Journal 10(1):3136. 